\title{
Between concept and metaphor: reviewing Nietzsche's doctrine of truth
}

\author{
Altaf Hossain \\ Jahangirnagar University, Dhaka-1342, Bangladesh \\ Email address: \\ altafju@hotmail.com
}

\section{To cite this article:}

Altaf Hossain, Between Concept and Metaphor: Reviewing Nietzsche's Doctrine of Truth, International Journal of Philosophy, Vol. 1, No. 1, 2013, pp. 6-20. doi: 10.11648/j.ijp.20130101.12

\begin{abstract}
For centuries, humankind accepts truth to be something static and global but Nietzsche has famously argued that truth is a metaphor and for that matter changeable and perennially evolving. As I hope to show here, this radical view has resulted out of Nietzsche's meta-commentary on language and logic. The main purpose of this article is to examine the key points of Nietzsche's arguments and the soundness of their conclusions, and thereby bring out their underlying critical intent.
\end{abstract}

Keywords: Nietzsche, Metaphor, Concept, Opposional Thinking, Truth of Becoming

\section{Introduction}

In the sections that follow, I argue that Nietzsche's claims do not discredit attempts at searching for truth, but eventually qualify these attempts so that the future search for truth becomes more self-reflective and aware of the role of language in conceptualizing truth. Nietzsche interrogates language and through it, to cite Klossowski, "[t]he near and distant future, a future that has now become our everyday reality - and he predicted that this future would be convulsive, to the point where our own convulsions are caricatures of his thought." While there are other features of his commentary, Nietzsche questioned the role of language by using it against itself. His proposal concerning the co-existence of essential untruth with the concept of truth reveals an extraordinary insight regarding our understanding of how language functions; but the radical nature of Nietzsche's arguments undercuts or forecloses his own purpose in writing. If words are nothing other than vague and flexible metaphors, and if language is incapable of expressing truth other than as empty tautology, then why would Nietzsche bother expressing himself in that mode in the first place? That language is metaphorical does not amount, for Nietzsche, to the contention that language cannot consistently express the world of objects. According to such a critique, the metaphor is as if an alien to the world of appearances, which is at best what Nietzsche called "a

\footnotetext{
${ }^{1}$ Klossowski, Pierre, Nietzsche and the Vicious Circle, (Chicago: The University of Chicago Press, 1997), p. Xv.
}

painting... unrolled once and for all."2 Thus metaphor, so construed, just presents an explicit comparison between a tangible object and another tangible or intangible object. While metaphor is a substitution of one term for another based on some similarity, metonym ${ }^{3}$ is a figure of speech in which a term is substituted by another based not on their similarity but on some granted association between the two terms. Anthropomorphism is a psychological phenomenon by which we personify an animal or an object with human qualities or, in keeping with Nietzsche's phrasing, "humanize" or subjectify discursive attempts at understanding the external world. Observing this general direction of how language functions, Nietzsche proceeds to critique the notion of truth and posits a view which Klossowski summarizes thus: "The intellect is a constraining and selective impulse - because of its very illusions." "To put it in even simpler terms, truth might trick or mislead us precisely because it is grounded in humanness.

\footnotetext{
${ }^{2}$ Friedrich Nietzsche, Human, All Too Human, trans. R. J. Hollingdale, (Cambridge: Cambridge University Press, 1996), p. 19.

${ }^{3}$ Metonymy is a figure of speech used in rhetoric whereby a thing or concept is not called by its own name, but by the name of something intimately associated with that thing or concept. For instance, 'Pentagon' is used as a metonym for 'American military'. The word 'metonym' derives

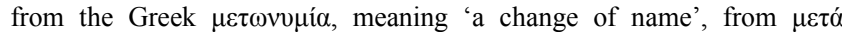
meaning 'after' or 'beyond' and Metonymy also may be contrasted with metaphor. Both figures involve the substitution of one term for another. In metaphor, this substitution is based on some specific similarity, whereas in metonymy the substitution is based on some understood association or contiguity.

${ }^{4}$ Klossowski, Nietzsche and the Vicious Circle, p. 254.
} 
At the outset, I lay out Nietzsche's views on metaphor based on his early books and unpublished materials. I also consider other related issues, namely, whether Nietzsche retained the literal/metaphorical distinction to the end and, if so, how that distinction could be applied to Nietzsche's own understanding of the world as Heraclitian becoming, or simply as the flux and incorrigible chaos of sensations. Even more pointedly, is the claim of truth as metaphor compatible with the traditional usage of true and false as logical opposites? Or, are truth and falsity oddly mixed in Nietzsche's portrayal of language as metaphorical?

\section{In What Sense Is Language Metaphorical}

The following excerpt from The Birth of Tragedy serves as a good starting point for considering the relation between truth and metaphor:

The sphere of poetry does not lie outside the world, like some fantastical impossibility contrived in a poet's head... the unvarnished expression of truth... The contrast between this genuine truth of nature and the cultural lie... is like the contrast between the eternal core of things, the thing-in-itself, and the entire world of phenomena."

Thinking along the lines of Schiller, Nietzsche portrays the complex entwinement of truth with poetic imagination and intuition. Poetry in Nietzsche's corpus needs to be deciphered in a wider sense, that is, as what he refers to as a fantastical feeling of mind that possesses the capacity to directly access the things themselves, or as an initial stage of reflection with immediate feeling-knowledge of the external world. Precisely at this level of awareness, Nietzsche's poet turns into an intuitionist philosopher who is endowed with a higher imaginative faculty or an intuitive ability, who can see through reality and beyond its categorical lay-out. Thus the philosopher-poet appears in Nietzsche's corpus as the real searcher of truth who can penetrate the sphere of consciousness to the point from which the knowledge-metaphor first originates. Nietzsche views this moment as a non-conscious and absurd psychic state. Just prior to the emergence of a discursive and critical mind, the poet-philosopher experiences existentially, and finds himself plunged in the unitary whole of the universe - a poetic universe, yet pointless and disillusioned. As depicted by Nietzsche, the existential poet, in such a delirious state of mind, is said to directly penetrate entities themselves without the mediation of symbols, and can therefore envisage what Nietzsche terms as "unvarnished expression of truth." Truth would be called fantastic only in this narrow sense, for truth originates from the infantile stage of conscious reflection which is deprived of any clear and distinct rational estimation. Nietzsche posits that this is

\footnotetext{
5 Friedrich Nietzsche, The Birth of Tragedy and Other Writings, ed. Raymond Geuss, trans. Ronald Speirs (Cambridge: Cambridge University Press, 1999), section 8, p. 41.
}

comparable to the mythopoetic feeling where the rules of distinctions or binaries (nature/culture, subject/object) do not apply yet. With this intellectual backdrop, Nietzsche examines the deep architecture of language and observes that metaphor as a linguistic category carries over something from one sphere (unvarnished impressions), and transports and transforms it into something else in another sphere (conscious/reflective sphere), where these two spheres are metaphorically, if not equivalently, linked. This theory of metaphor represents a radical stance concerning the relation between metaphor and truth, and has provoked a number of polemics because it seems to contradict humankind's taken-for-granted privileging of literal language over the figural. Because, it jeopardizes our common sense belief that truth which is expressed in literal language corresponds to some objective state of affairs in the external world. There are fundamental disagreements as to what is meant by literal language. Some may restrict the literal to the everyday meaning established by common convention, such as the statement 'The cat is on the table.' Some others may delimit literal language to the observation words and sentences supported by scientific theories or hypotheses. But all such claims make a privileged point that language and the world somehow come into direct contact with each other. Quoting Quine would be helpful to clarify my point here:

The total field [of forces] is so undetermined by its boundary conditions, experience, that there is much latitude of choice as to what statements to re-evaluate in the light of any single contrasting experience. No particular experiences are linked with any particular statements in the interior of the field, except indirectly through considerations of equilibrium affecting the field as a whole. ${ }^{6}$

Hence Quine finds it difficult to detect any one-to-one connection between a single statement and its contrasting phenomenon. The indeterminacy in question does not, as Quine hints, arise out of our inability to find out the corresponding facts or sensations, but rather from the lack of demarcatedness between facts (chaos). For this reason, the atomicity of experience needs to be matched with a particular utterance. Thus interpreted, the field of experience appears far more wide-ranging than is usually thought, and stretches across the whole chaos or forces of perception. If our sensuous experience is taken strictly, then it blurs its own peripheral demarcation and dissolves the separatedness of determinate facts, which implies that we need a demanding criterion for literal meaning. Within this restricted space of understanding, sentences that only join proper names and definite facts would qualify as true. If we grant this strict criterion for the literal, then all statements other than those that express "absolutely singular primal experience" would be deemed metaphorical. But it is evident that Nietzsche is far removed from such a Wittgensteinian dilemma.

In On Truth and Lying in a Non-Moral Sense, Nietzsche

\footnotetext{
${ }^{6}$ William van Orman Quine, From a Logical Point of View (New York: Harper and Row, 1963), pp. 42-43.
} 
focuses on the metaphorical motion of life-world and argues that, at each stage of human perception, the fundamental material of perception, "nerve stimuli," is transferred from one domain to another, just as in metaphorical expression two distinct entities are metaphorically equated. "The stimulation of a nerve," writes Nietzsche, "is first translated into an image: first metaphor! The image is then imitated by a sound: second metaphor! And each time there is a complete leap from one sphere into the heart of another new sphere." It is crucial to note that, in this passage, Nietzsche is using the word metaphor metaphorically so as to indicate the fact that it is not really a metaphor by definition, but rather that there is only a metaphorical comparison between nerve impulse and image. Based on this sort of definition of metaphor, Nietzsche insists that all symbolic communication is imperfect because this leap, this subjective apprehension of an objective world, has been incorporated into the architecture of language itself. In the process of every word formation, such as Nietzsche's example of leaf, a similar leap happens: from a "unique, utterly individualized, primary experience" to the concept of leaf through the equation of "countless other, more or less similar cases." As Nietzsche writes: "Every concept comes into being by making equivalent that which is non-equivalent... that no leaf is ever exactly the same as any other leaf... that the concept leaf is formed by dropping out these individual differences arbitrarily. ${ }^{9}$ Thus by identifying an inner flexibility in language, Nietzsche widens the scope of a metaphor's connotation even to include the sense of analogy, and thereby suggests that a knowledge-concept is as if a tightly "packaged bundle of analogies." In the domain of language, we move from one analogy-bundle to another and, interestingly, this leap from concept to concept is made via analogical connection. ${ }^{10}$ The role of imagination plays a key role in the formation of knowledge-concepts where, Nietzsche maintains in a tone mimicking Schopenhauer's aesthetics, philosophy takes the lead over poetry. Given the nature of this initial state of human experience, the poetic-mythic feeling is to be "understood as a complex of unconscious representations and states of will."11 Further on in the same excerpt, and in response to the question "In what way does feeling convey itself?" Nietzsche remarks:

It [feeling] can be transposed into thoughts... into conscious representations... the dissoluble part that language... [precisely] concepts, has anything to do with; this defines the limit of 'poetry'

\footnotetext{
${ }^{7}$ Friedrich Nietzsche, On Truth and Lying in a Non-Moral Sense in The Birth of Tragedy and Other Writings, eds. Raymond Geuss and Ronald Speirs, trans. Ronald Speirs (Cambridge: Cambridge University Press, 1999), p. 144

${ }^{8}$ Ibid, p. 145.

${ }^{9}$ Ibid.

${ }^{10}$ Douglas R. Hofstadter, "Epilogue: Analogy as the Core of Cognition" in The Analogical Mind, eds. Dedre Gentner, Keith J. Holyoak and Boicho N. Kokinov (Massachusetts: Massachusetts Institute of Technology Press, 2001), p. 500.

${ }^{11}$ Nietzsche, On Truth and Lying in a Non-Moral Sense, p. 134.
}

as far as its ability to express feeling is concerned. ${ }^{12}$

In her effort to synthesize Nietzsche's corpus, Kofman makes the same point, opining that Nietzsche gives special significance to the analogical imagination which prompted him to assert that philosophy remains "a prolongation of the mythic instinct." ${ }^{13}$ However, the act of perception for Nietzsche is inherently metaphorical, since it necessitates language as an independent sphere to be relationally connected, and such relationality is absent in the inorganic sphere where objects just appear as they are. As Nietzsche proclaims in the Notebooks:

It is in the organic world that error begins... They [substances, activities, truths, and the like] are the specific errors which enable organisms to live. ${ }^{14}$

In accordance with such a viewpoint, human life turns out to be as though it were the highest specialization having the greatest loss, because the very excellence of organic life brings us the error or narrowness of perspectivity. On the contrary, the inorganic sphere amounts to the "greatest synthesis of forces," which is perfect and complete on own. ${ }^{15}$ Here, Nietzsche understood error in an existential sense, where "the opposition is not between the true and the false... [but] what's essential is the evolution of forms which represent many movements, the invention of signs for whole species of signs." 16 In other words, the existential progression of life inherently carries a metaphorical fluidity within it, by transferring meaning from one stage to another and thereby renewing humankind's adjustment in and with the world.

The human intellect for Nietzsche is arrogant and self-delusional, and yet it has the capacity for transforming the original delirious metaphors into distinct concepts, into what Nietzsche labels as "worn-out" metaphors. This capacity for sublimation from mere sensuous impressions to conceptual schemata in fact marks a distinguishing characteristic between humankind and other beings. ${ }^{17}$ But since the intellect is naturally forgetful of the event that this transference has originally occurred between two distinct spheres, it deems the conceptual schemata to be the thing-in-itself. As a result, Nietzsche would argue, truth and, by extension, the entire process of communication turns out to be metaphorical. It is the power of conceptual schemata that has brought about a distinctly human world which is invested with "peace, security and consistency," but this does not really explain what Nietzsche calls the "drive to form metaphors, that fundamental human drive which cannot be left out of consideration for even a second without also leaving out human beings themselves." 18 The

\footnotetext{
12 Ibid.

${ }^{13}$ Sarah Kofman, "Metaphor, Symbol, Metamorphosis" in The New Nietzsche, ed., Allison, p. 209.

${ }^{14}$ Nietzsche, Writings from the Late Notebooks, trans. Kate Sturge, ed. Rudiger Bittner (Cambridge: Cambridge University Press, 2006), p. 28.

${ }^{15}$ Ibid., p. 62

${ }^{16}$ Ibid., p. 28

${ }^{17}$ Nietzsche, On Truth and Lying in a Non-moral Sense, p. 146.

${ }^{18}$ Ibid., p. 150-151.
} 
rational-scientific intellect utilizes and stifles this drive during the formation of conceptual abstractions, as Nietzsche compared this mechanism to the art of making honey-combs: "Science works... at that great columbarium of concepts, the burial site of perceptions, [and] builds ever-new, ever-higher tiers, supports, cleans, renews the old cells." ${ }^{\prime 19}$ While a rational person is inventive and seeks out a new province of his or her thought-experiments, intuitive minds instinctively see the lived world as a chain of metaphors that Nietzsche thought are universally present in the mythical and artistic impulses. ${ }^{20}$ The intellect of intuition, artists or myth-makers, constantly confuse the "classifications of concepts... [and] manifest the desire to shape the given world... as multiform, irregular, inconsequential, incoherent, charming and ever-new." 21 Given this self-conscious and recurring exercise with metaphors, the existential mind learns to adapt to and with its inherent flexibility, and thereby lives with the world metaphorically. By viewing the lived world as a unity, Nietzsche risked to cross the limit of categorical knowledge, as well as the boundary of human life itself. The early Nietzsche was unaware of the basic fact that it is only thinking through opposition and division that we can make our life possible, and thereby translate the silence of natural unity into the sound of knowledge. As Nietzsche himself describes this mechanism elsewhere, "Nature knows neither forms nor concepts and hence no species." 22 In this narrow sense, humankind can see through the unity of nature by devising and employing the conscious-conceptual structures, and in that way creates dichotomies between the individual and the species. But although such opposition is "anthropocentric and does not stem from the essence of things," it would be "a dogmatic assertion," thinks Nietzsche, to affirm that it does not correspond to the thing-in-itself either. ${ }^{23}$ To absolutize objects with essences is a prerequisite for knowledge, which is supplemented by attempts at logicizing and categorizing. But absolutization for Nietzsche is not aimed at absolute truth; rather, it provides us with the means for us escape from the discomfort of the absolute unknown or total ignorance. Unlike a dogmatic thinker, Nietzsche's philosopher-poet is a conceptual artist, and he or she is aware of the non-absolute nature of conceptualization which reveals itself in an ever-flowing creative mode of language.

The early Nietzsche configured the life-world as a true-lie, but his post-tragic thinking is still ensnared by the "imperturbable belief that thought, as it follows the thread of causality, reaches down into the deepest abysses of being, and that it is capable, not simply of understanding existence, but even of correcting it." 24 Out of the possibility of a new

\footnotetext{
19 Ibid., p. 150.

${ }^{20}$ Ibid., p. 151

21 Ibid.

${ }^{22}$ Ibid., p. 145.

23 Ibid.

${ }^{24}$ Nietzsche, The Birth of Tragedy, p. 73.
}

philosophical intellect, Nietzsche portrays the philosopher after the image of a dying Socrates, an image of "a man liberated from the fear of death by reasons and knowledge." 25 The modern scientific impulse is underpinned by this ideal. As Nietzsche notes in Human, All-too Human, the "genius of every kind" must be cautious of his unexamined beliefs and authority, which thereby "awakens [in him] distrust of the modesty and circumspection of science." ${ }^{26}$ Nietzsche's criticism thus presupposes the typical Socratic temperament: questioning of what is unexamined in life, because an unexamined life is the worst "enemy of truth than lies."27 But Nietzsche further insists that the critical harakiri of philosophy has to be soberly mixed with this artistic vision, so that our sweet illusions should not abrogate the inner flexibility of life. The new philosophical enterprise, then, would be a "heraldic shield over the portals of science, reminding everyone of its purpose, which is to make existence appear comprehensible and thus justified." 28

In his early error theory, Nietzsche draws attention to the way in which the intellect might trick us by creating inauthentic mental models of existence, or might offer conceptual sets of fallible and imprecise motives. In such a depiction of the deceitful character of the human intellect, Nietzsche reexamines both the genealogy and value of truth in the spheres of human interaction. In the following excerpts, Nietzsche portrays the tension between the two primordial conditions of humankind, the natural/misanthropic versus the social/philanthropic. As Nietzsche observes:

In the state of nature he [mankind] mostly used his intellect for concealment and dissimulation; however, because ... men want to live in societies and herds, they need a peace treaty... this peace treaty, however, comes [from] something which looks like the first step towards the acquisition of that mysterious drive for truth... i.e. a way of designating things is invented... [which] also produces the first laws of truth, for the contrast between truth and lying comes into existence here for the first time. ${ }^{29}$

The state of nature Nietzsche speaks of here is the Hobbesian primitive stage of anarchy, the "bellum omnium contra omnes," 30 which precedes the founding of civil society. What Nietzsche calls a peace treaty is a concordance of humankind to create a new agreement, and that entails the creation of truth. The rationality of general consensus had to be invented for the preservation of the subjects as viable social-moral agents, and humankind still continues to endure the legacy of this good old friend with pride and confidence. Nietzsche spoke of this legacy more explicitly in Daybreak:

\footnotetext{
25 Ibid.

${ }^{26}$ Nietzsche, Human, All Too Human, p. 202.

${ }^{27}$ Ibid., section 483, p. 179.

${ }^{28}$ Nietzsche, The Birth of Tragedy, p. 73.

${ }^{29}$ Nietzsche, On Truth and Lying in a Non-Moral Sense, p.143.

${ }^{30}$ The "struggle of all against all," a phrase associated with Hobbes's description of the state of nature before the institution of political authority came into play (The Leviathan, Chapter XIII).
} 
Nothing has been purchased more dearly than... human reason and feeling of freedom that now constitutes our pride." ${ }^{31}$

Within this framework of the human life-world, Nietzsche rethinks the notion of freedom as a restricted social phenomenon, which would be realized via the mode of sociality within the sphere of shared social practices and activities. Nietzsche further remarks: "This morality of custom... precedes 'world history' as the actual and decisive era of history which determined the character of mankind. ${ }^{, 32}$ While primitive forms of society were evolving, Nietzsche imagines, individual subjects were mostly driven by their instinctual motives, and thus by the strong belief that "mankind [is] the goal of nature" and "nothing could be disclosed by knowledge that [is] not salutary and useful to man."33 Later in his career, however, the mature Nietzsche extends this ideological voice as to the discussion of truth, that is, its pivotal role in shaping society and saving human agency. In this regard, he emphasizes the collective strength of consensuality and agreement, which he summarizes in a passage entitled "For Whom Truth Exists?" in Daybreak: "Truth, as a whole and interconnectedly, exists only for souls which are at once powerful and harmless, and full of joyfulness and peace." ${ }^{34}$ Nietzsche, however, believes that the intellect possesses a simulating capacity, and so does the every conceptualization. Despite his claim that truth is a form of tautology ${ }^{35}$ or empty husks, ${ }^{36}$ Nietzsche educates us about how we can live boldly and courageously through and with the truthful lies that are inevitable, or even how not to hesitate to avoid truths if they are unpleasant.

Nietzsche expands this view by focusing on the syntactical trickery of linguistic conventions, and addresses some of the rhetorical questions related to conventional rules. In a polemical response to the question "What is truth?," Nietzsche summarizes his observations in a famous passage which is worthwhile citing at length:

A mobile army of metaphors, metonymies, anthropomorphisms, in short a sum of human relations which have been subjected to poetic and rhetorical intensification, translation, and decoration, and which, after they have been in use for a long time, strike a people as firmly established, canonical, and binding; truths are illusions of which we have forgotten that they are illusions, metaphors which have become worn by frequent use and have lost all sensuous vigour, coins which, having lost their stamp, are now regarded as metal and no longer as coins. ${ }^{37}$

Nietzsche uses the term metaphor here to indicate the inscrutable make-up of linguistic phenomena. In other words, truth or, by extension, knowing is "tracing something

\footnotetext{
${ }^{31}$ Nietzsche, Daybreak: Thoughts on the Prejudices of Morality, trans. R. J. Hollingdale, eds. Maudemarie Clark and Brian Leiter (Cambridge: Cambridge University Press, 2206), Book 1, p. 17.

${ }^{32}$ Ibid.

${ }^{33}$ Ibid, Book 4, Section 424, pp. 181-182.

${ }^{34}$ Ibid.

${ }^{35}$ Nietzsche, On Truth and Lying in a Non-moral Sense, p. 144.

${ }^{36}$ Ibid.

${ }^{37}$ Ibid, p. 146.
}

alien back to something [which] one is acquainted and familiar with." ${ }^{, 38}$ Nietzsche observes that metaphoricity may be unavoidable in the formation of truth or an ideal. This is a kind of inner process in language-making as such, which is mystified as sweet illusion or an existential forgetting when truth is "established," "canonized," and assumes a functional value for life. In the transition from animal trait to discursive type, the human species must have endured and valorized this forgetting in order to live in the life-world as the most comforting illusion, such that existential alienation is no longer a riddle. While we affirm our authentic existence through mutuality and recognition of otherness in the shared space of society, Nietzsche claims that the "feeling of the new, of the discomfiting, is dulled: everything that happens regularly no longer seems questionable to us." ${ }^{39}$ In his unpublished notes, Nietzsche contends that the repetition of acts or events builds up our "sense of causality," that the knower's first instinct is to discover the rules of knowledge based on the regularity of experiences, and knowing only takes place "where the regularity of phenomena allows [us] to apply abbreviating formulas." 40 As the knowledge-beings, we suffer the prospect of standing out with the uncertain, unknown and unpredictable, while "intellectual security is the soothing of [this] fearfulness" that "lulls to sleep the questioning (i.e. fearing) instinct," and domesticates the "dangerousness of the arbitrary." "41 Thus the rules of language and logic, Nietzsche posits, offer humankind the "art of schematizing and abbreviating, a coping with multiplicity through an art of expression," and "a designating in order to make oneself understood." ${ }^{42}$ Despite the fact that our senses work under the command of an anthropocentric ego, as well as other species-specific traits and needs, and so create phantasmic sweet lies, Nietzsche insists that we should hold on to the testimony of the senses with an attitude of revaluation, which formulates the Zarathustrian urge for continual overcoming:

The best intellectual men feel the stimulus and spell of sensual things... they are sensualists in the best of faith, because they accord a more fundamental value to the senses than that fine filter ["hearts of flesh"/ "mind"], the apparatus of dilution and miniaturisation.",43

While language works metaphorically, Nietzsche nonetheless maintains that " $\mathrm{t}]$ he most essential thing in a well constituted and complete man" is to conform to the "force and power of the senses" - the real spirit and magnificence of all humanization. ${ }^{44}$ Above all, Nietzsche reaffirms that faith in senses and their testimony is the best option for knowledge and the real source of "true and actual progress" ${ }^{45}$ for the human race.

\footnotetext{
${ }^{38}$ Nietzsche, Late Notebooks, p. 107.

${ }^{39}$ Ibid.

${ }^{40}$ Ibid.

41 Ibid.

42 Ibid, section 5[16], p. 109.

${ }^{43}$ Ibid, section 5[34], p. 110

44 Ibid.

${ }^{45}$ Ibid., section 15[60], p.269.
} 
In a certain sense, the early Nietzsche is a linguistic idealist who at times interprets truth as a linguistic phenomenon which results from the interplay of logical principles and grammatical conventions. It is obvious that, in order for us to be a discursive type of creature, we are required to strictly abide by the rules and logic of language because "the legislation of language... produces the first laws of truth." 46 These rules and this logic have, namely, an essential effect on the intralinguistic distribution of significations and the production of truth. Since it is evident that there are cases of deception where truth is misused or manipulated, the early Nietzsche is concerned with linguistic trickery in general, which he thought generates a certain "validity and force" $" 47$ in symbolic interactions. Thus in social-moral spaces, the demarcation between truth and falsity may be intentionally blurred owing to selfish motives or personal gains, thereby presenting illusions of truths as if they were actual truths. Using words as the "valid tokens of designations... to make the unreal appear to be real," a liar manages to represent himself as rich while he is in actual life poor. Nietzsche thus contends that while using language one could "misuse the established conventions by arbitrarily switching or even inverting the names for things," 48 and so could thereby manipulate/betray the convention of language. Observing these features of language, Nietzsche insists that critical analysis of syntactic characteristics helps us to track the hidden meaning of words or sentences, depending on their focus, emphasis, choice of grammatical categories, and the direction and focus of the claims they intend to make. Every report on an event or occurrence adopts certain linguistic strategies to represent that event or occurrence. Choosing certain metaphors instead of others, a reporter can manipulate an event and make certain special effects (cultural, political or aesthetic) inside the text, and thereby represent a new perspective of that given reality or event. These linguistic strategies (metaphorization, nominalization, placement and the omission of agents in the utterances) often foreground or background the mechanisms of power-play between speakers and audience. These conventions, Nietzsche observes, are naturalized in various modes and degrees across different language systems. On the one hand, the process of word formation is greatly influenced by the culture-specific norms of linguistic communities. Consensus concerning these rules and norms has to be established prior to their operation in a language community. But these intralinguistic choices and preferences have very little to do with truth and referential meaning. On the other hand, Nietzsche observes that the constitution of a word depends on the rule of sameness, that is, the logic of identity, which tends to equate similar features of an object under a singular or unique concept: "Every concept originates through our equating what is

\footnotetext{
${ }^{46}$ Nietzsche, On Truth and Lying in a Non-Moral Sense, p. 143.

47 Ibid.

${ }^{48}$ Ibid., p. 143.
}

unequal." "49 Thus the process originates from a "unique and wholly individualized original experience." According to Nietzsche's linguistic analysis, conceptualization as a linguistic process misses and ignores dissimilar aspects amongst objects, and does not incorporate these dissimilar aspects into the process of concept-formation. This procedural negligence or exclusion of dissimilarities worried Nietzsche in his early years because it is inherent in the universalizing process of conceptualization and remains unquestioned throughout traditions. But Nietzsche never asked what deeper implications it might bring vis-à-vis truth or what difference this exclusion really makes at the pragmatic level beyond its purely linguistic consideration. While we designate a generic term to encapsulate a particular family of objects, such as the idea of oval-shaped table, we as language users are equally aware of the fact that there still remain countless individual oval-shaped tables with their unequal qualities which lie outside the process of conceptualization. With his discomfort over the unquestioned adoption of the logic of identity in particular, and rules of thought in general, Nietzsche cautioned us about the potential misuses of language and the misrepresentation of reality to which it gives rise. ${ }^{50}$

What Nietzsche's radical critique is intended to show is precisely the limit of our epistemological inquiry, which is functional at the core of our existential modes of being. Nietzsche's main concern is to reveal how truth was first produced in relation to the subjective grasp of humankind, and not how it was linguistically laid out later on. His critique of reason, and especially the role it plays in abstracting and generalizing, is thus derived from a deep-seated tension in human existence: "Everything which distinguishes human beings from animals depends on this ability [of reason] to sublimate sensuous metaphors into a schema, in other words, to dissolve an image into a concept."51 In the Nietzschean hermeneutic of language, this existential tension manifests itself through the restless movement of metaphor, and language is deemed an encompassing web that tailors primary images/impressions together, where this "pyramidal" transference of the "mysterious X" of things themselves into the knowledge-concept is taken as a tremendous invention of humankind. But this transference, according to Nietzsche, does not bring falsity to linguistic expression at all; rather, it is an intriguing combination of factuality and fictionality (i.e. true and illusion), because this transformation is metaphorical, and draws on first impressions or facts from things themselves, but ends up being mixed with anthropocentric interests, needs and preferences.

\section{In What Sense Is Truth a Metaphor}

\footnotetext{
${ }^{49}$ Nietzsche, The Portable Nietzsche, trans. \& ed. Walter Kaufmann (New York: Penguin Books, 1976), p. 46.

${ }^{50}$ Nietzsche, Philosophy and Truth, p. 81.

${ }^{51}$ Nietzsche, The Portable Nietzsche, p. 146
} 
The early Nietzsche understood language not as a passive domain of stable significations, but as a dynamic and productive medium that fits well within his existentially inspired framework. From this vantage point, Nietzsche understood knowledge-concepts as metaphors, and seems to propose the liberal usage of concepts across language systems in order to create free spaces for creative analysis which, he thought, traditional metaphysics oriented systems lack. Nietzsche maintains that the theoretical alliance with metaphors would supply us with more freedom and a wider array of options to affirm the experience of the life-world without being locked into a Parmenidean world-view. Understandably, Nietzsche's thesis that truth is metaphorical rather than logical has caused inconsistencies throughout his body of writings. Many influential scholars like Kaufmann think that Nietzsche's contradictions can be better understood once we follow the reasons for his fragmented and aphoristic style. Kaufmann's Nietzsche is indeed a "Platonist" who "is, like Plato, not a system-thinker, but a problem-thinker," systematic thoughts than to offer question-oriented improvisations. "Nietzsche's philosophically grounded objections to system building," to argue with Nehamas in this context, are informed by his "preference for posing questions rather than for giving answers." 54 Although there are obvious discontinuities in Nietzsche's corpus, where a "great number of experiments" $" 55$ have been assembled in each of the individual aphorisms, Kaufmann nevertheless holds that the aphorisms are unified not by their content, but by their usage as "thought experiment [Versuch]." ${ }^{56}$ But Nehamas notices that Kaufman is determined to "show that Nietzsche's aphorisms are ultimately unified"; 57 that "a whole philosophy" "58 "or "an underlying unity" even though the "unity... is obscured but not obliterated by the apparent discontinuity in his experimentalism." 60 Importantly, Nehamas continues, each of these aphorisms serves as a correction to his previous writing. To put it in simpler words, the radical break or discontinuity indicates Nietzsche's realization of prior errors up to that point. It is in this sense only that Nietzsche's aphoristic writing is to be understood as an experiment or test. Kaufmann argues that experiment, for Nietzsche, is not quite the same as is generally understood: its characteristic feature is existential, and it is in fact equivalent to "testing an answer by trying to live according to it." ${ }^{, 61}$ In contrast to Socratic dialecticism,

\footnotetext{
${ }^{52}$ Kaufmann, Walter, Nietzsche: Philosopher, Psychologist, Antichrist (Princeton: Princeton University Press, 1974), p. 268.

${ }^{53}$ Ibid., p. 82.

${ }^{54}$ Alexander Nehamas, Nietzsche: Life as Literature, (Harvard: Harvard University Press, 1985), p.15.

${ }^{55}$ Kaufmann, Nietzsche, p. 85.

${ }^{56}$ Ibid.

${ }^{57}$ Nehamas, Nietzsche, p. 15.

${ }^{58}$ Kaufmann, Nietzsche, p. 74

${ }^{59}$ Nehamas, Nietzsche, p.15.

${ }^{60}$ Kaufmann, Nietzsche, p. 91

${ }^{61}$ Ibid., p. 89.
}

Kaufmann wrote, "Husserl's phenomenology and contemporary Existenzphilosophie are at one with Nietzsche." 62 On Kaufmann's account, aphorisms are constitutive parts of Nietzsche's efforts to tease out errors that could be otherwise hidden in his prior works. On Nietzsche's part, this amounts to an attempt to circumvent the problem of language as well as provide scope for existential and creative interpretations. But Kaufmann's correction thesis may not be adequate for revealing what Nietzsche had in mind about metaphor in particular and language in general. This is because Kaufmann's interpretation is based on the presupposition that there are more proper things for Nietzsche to have said, or that there are truer grounds to stand to judge his prior claims. Thus the claim that Nietzsche tends to correct his previous opinions, and even by experimenting through and with the aphoristic style, would need to be adjusted in keeping with what Nietzsche means by perspective, relativism and pluralism. Kaufmann's classic account, however, remains a reflective source for a further survey of Nietzsche's pluralism and perspectival view of truth in particular, and his account of knowledge in general.

Much like Kaufmann, Kofman thought that aphorisms play a key role in Nietzsche's philosophy, but at the same time she significantly builds on, and even improves, Kaufmann's account. Kofman offers a different interpretation of Nietzsche's experimentalism which is open-ended, and is not merely corrective. According to Kofman, Nietzsche uses metaphor to grasp the wider horizon of interpretations that are contained in his aphorisms, and does not use it to limit that range to correction. So we can argue, based on this view, that artistic activity is for Nietzsche essentially grounded in an unconscious and indefinite state which effaces tendencies to oppose reality and appearance. This view of metaphor opens up a worldview that "without man the world would not exist and would have no meaning." 63 The idea of life as art, writes Nietzsche, "invents forms, posits values and meanings which, in its absence, the world would find itself lacking." Thus poetry, as a typical or fundamental form of art, is a domain where language is employed in its highest aesthetic mode in addition to its literal or semantic significance. But Nietzsche does not claim that metaphor altogether lacks empirical content, and is therefore fully an artistic or poetic production. To take Nietzsche to have made such point would be disastrous; it would be, as Kofman remarks, "a betrayal of Nietzsche" for whom "philosophy, if it is not science, is not poetry either.",65

However, at this point it is important to critically focus on Nietzsche's laborious effort towards a literal-metaphorical model. In this synthesized model of metaphor and concept,

\footnotetext{
62 Ibid., p. 84.

${ }^{63}$ Kofman, Nietzsche and Metaphor, trans. Duncan Large (London: The Athlone Press, 1993), pp. 32-33.

${ }^{64}$ Ibid., p. 33.

65 Ibid., p. 1 .
} 
images or first sensations initially originate from unconscious and artistic impulses, but are eventually transposed "into the world explanatory schemata which man fashions after himself." 66 But this movement, within the purview of Nietzsche's philosophic intuition, is not just anthropocentricism by another name. Explanatory schemata express our lived-world in a fictional yet truthful manner, so to speak. The expression happens via a transportation of the unconscious fancies to the conscious and discursive domain of truth and falsity. The disclosure of the lived-world by metaphors thus appears to Nietzsche an improper and untrue form, while at the same he admits that there is no other way to reveal it. Using metaphors to understand the lived-world, Nietzsche would argue, one can live one's life more authentically: granting one more freedom and life-affirmation, thereby remaining committed to one's own experiences. Grasping what is given to him and transposing it to something else (the process of metaphor-making), we tame, so to speak, our life-experience "by the "camera obscura' or sifted through consciousness." world is not a linguistic world: it is given and independent, but it is reborn and reworked through language which, to cite Kofman, "symbolizes a text written originally by unconscious activity" by masking and transposing (metaphorizing) what was in raw sensations. ${ }^{68}$ It is in this sense that metaphorization is always already functional at the core of our organic lived-world. As a form of 'will' in the mind, the metaphor creates unity out of diversity by restricting and subjugating the 'unknown' and unfamiliar. As for outcomes, the known and the familiar gain the status of truth and the proper, and the life-experience is transported, metaphorically and metonymically, everywhere. To say that metaphors are rampant in human spheres and make us more human is not to get trapped in Berkeleyean solipsism, but rather is to argue that in metaphorization, as Kofman summarizes, "objectivity coincides with subjectivity." In this specific sense, the affirmation of one's life means multiplying metaphors in order to create a plurality of viewpoints. Seen From this angle, the affirmation of life operates in a chain of metaphors which all seekers of truth must work under. Life embodies and advances in the fluidity of metaphor, what Nietzsche later called amor fati. ${ }^{69}$ In such an illustration of metaphor, the concept gains a privileged status and a higher mode owing to the forgetfulness of the initial process of perception: making the different and dissimilar objects and attributes the equal and the similar. At the level of conceptualization or concept-formation, precisely this metaphorical fluidity, as well as its forgetting in turn, restores humankind's discursive consciousness. Or as Kofman writes: "Man arranges the whole universe into well-ordered logical categories without realizing that he is

\footnotetext{
${ }^{66}$ Ibid., p. 33.

${ }^{67}$ Ibid.

${ }^{68}$ Ibid., p. 33.

${ }^{69}$ Ibid., p. 102.
}

thus continuing the most archaic metaphorical activity." concept, for Nietzsche, expresses the world truthfully not because it is an a priori idea or model, but because it is a lasting and solidified impression that is compatible with the external world, and is reworked through the rules and norms of thought and language.

Reiterating Heidegger, Kofman writes that Nietzsche "remains ensnared in the same system of thought as the metaphysician." 71 But Nietzsche is not the same metaphysical thinker as his predecessors Plato or Descartes; for in Nietzsche's thinking about metaphor, the question whether language is conceptual or metaphorical is obsolete: the traditional dichotomy of these two categories cannot be applied to Nietzsche. In the early corpus (The Birth of Tragedy and Philosophy in the Tragic Age of the Greeks), Nietzsche depicts metaphor as the "fundamental operator" 72 that works, and is rooted in the "innermost essence of things, independent of the metaphor which symbolizes it." ${ }^{, 73}$ In The Birth of Tragedy, Nietzsche configures Dionysian ecstasy as an insight according to which this fundamental operator assumes several other similar expressions, such as "transfiguration," "transformation," "self-dispossession" and "metamorphosis." Nietzsche set out two separate criteria to define the metaphorical and the conceptual, and used the illogical (intuition) against the logical (concept) as though the illogical is the domain in which the conceptual has no role. Metaphorization for Nietzsche is the "abyss" in human thought which has been revealed by metaphysical efforts throughout the philosophical tradition. In the later writings, the process of metaphorization is effaced as a strategic notion or simple interpretation, where metaphor is a "symbolic of the artistic force of interpretation" that consists of both the proper (the concept) as well as metaphor.",74

\section{Thinking through Opposites and the Truth of Becoming}

Nietzsche summarizes his observations regarding the psychological origin or motif of humankind's oppositional thinking in a passage of late Notebooks as follows:

This world is illusory - consequently there is a true world. This world is conditioned - consequently there is an unconditioned world. This world is contradictory-consequently there is a world free of contradiction. This world is a world that becomes consequently there is a world that is... These conclusions are inspired by suffering: at bottom they are wishes that there might be such a world; in the same way, hatred of a world that makes us suffer expresses itself in the imagining of a different world, a valuable one. ${ }^{75}$

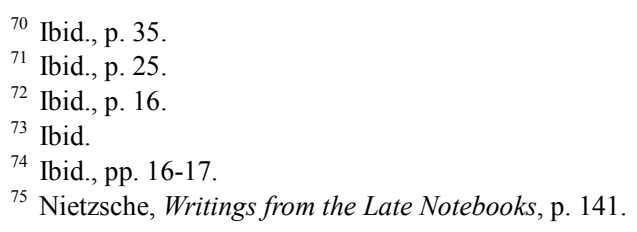


Nietzsche's becoming is "an always mobile substratum" because, at its core, there is a "subterranean mobility" which causes existential anxiety in us, what Klossowski calls the "substratum of ... pathos."76 The inner conflicts of life and its heroic overcoming in the lives of mythic figures mesmerized Nietzsche to the point that, in his youth, he took Silenus's pathetic yet existential discernment of mankind's fate as a great teaching: "No one has chosen to be born as such; the choice was made outside of us - the 'outside' we designate as fate." $77 \mathrm{He}$ hence ventured to synthesize becoming with the transitoriness of life and its valuation. This juvenile sentiment moved Nietzsche to the Dionysian worldview, wherein he found human existence fragmented between an irresistible urge to break the command of fate and limitations thereof. But the later Nietzsche evaded this impasse by espousing a type of artistic affirmation of the life-world within this world, a world that is devoid of any other-worldly premise or promise. Nietzsche's existential obsession with the unconditioned, with a value-free condition per se, thus necessarily presupposes the conditioned and the given. For Nietzsche, to err of becoming as thing-in-itself or truth is an all-too human habit because this urge is a primitive and deep-seated necessity of humankind, "an essential condition for the abolition of suffering." 78 Thus the dichotomy between the given (outsideness) and the created (insideness) is overcome and dismantled by the existential contention that "[r]eality corresponds to one of them,"79 namely, to the one that we interact, adapt and grow up with, the everyday world of change and becoming.

Nietzsche's life-long concern is to redefine the Platonic-Cartesian conception of the subject and offer a renewed configuration of it as an all-too-human subject that would emerge as a new cultural anthropology in his contemporary culture. But the configuration of such subjects depends on Nietzsche's success in solving the theoretical conflict concerning the articulation of the metaphysics of becoming as opposed to his denial of the metaphysics lurking behind becoming. Thus, by avoiding the perennial issue of the insideness and outsideness of an external world, Nietzsche opts for a third path: a monistic view which redefines becoming as "life and experience." 80 This life-experience is much like a "painting," a coloured "course of becoming" which embodies change and the precariousness of human existence. As a prerequisite of the principle of sufficient reason, authentic human existence seeks out for a point of origin. Plunged in the "moral, aesthetic and religious demands on the world," humankind subsequently fuses blind fear, passion and desire with the intellect, and in that way projects his anxieties and worries

\footnotetext{
${ }^{76}$ Klossowski, Nietzsche and the Vicious Circle, p. 254.

${ }^{77}$ Ibid.

${ }^{78}$ Nietzsche, Writings from the Late Notebooks, p. 142.

79 Ibid.

${ }^{80}$ Nietzsche, Human, All Too Human, p. 20.
}

onto entities and makes the world appear. ${ }^{81}$ Humankind, discerns Nietzsche, began its journey from this root, and thus in every truth and valuation "the whole pre-history of the organism is at work." 82 While Dionysianism is unavoidable and rampant in the human senses and perceptions, Nietzsche ventured to portray an anthropocentric character of truth in particular and knowledge in general.

Nietzsche began his early essay focusing on humankind's delirious struggle with nature, with the existential mode of Dionysian subjects before the restoration of their consciousness, rational orientation and participation in the surrounding world. In the primordial condition trodden by war, isolation and melancholy, Dionysian types lived in continual fear of the unknown and unpredictability. Shattered by existential precariousness, humankind constantly strives to be what it is not yet: overcoming the past and creating new truths or ideals, what Nietzsche calls true-falsities. Before a fully-fledged cognitive type had emerged, Nietzsche speculates, humankind "long existed and far more richly, without consciousness." $" 83$ Only at a later stage did he acquire a "sense of time, place and causality" as a priori categories for "certain simplest, plainest [and] most reduced form... of a much more comprehensive willing-feeling-thinking." 84 Predisposed to break through existential precariousness, humankind must work out truths which are useful forms for life, thereby renovating relationships with the surroundings. The subject so envisaged is competent in his or her ability to invent and integrate new standards and beliefs in his or her use of the old concepts, and in so doing might be disillusioned by the outlandish and new facts of life; but he or she surely lives with increasing self-determination and intellectual honesty. As Nietzsche suggests in Beyond Good and Evil, the subject lives with the "playful hunch that things are not one way or the other, that people just accept things as one way or the other." $" 85$

Perhaps two of Nietzsche's key premises are worth-mentioning at this point: 'untruth is the condition of life', and the 'human being is a Dionysian child'. These premises jointly interrogate the traditional distinction between truth and falsity as logical opposites. Since knowledge is an inescapable hunch of the knower, Nietzsche insists that the "falsity of a judgment is not... an objection to [it]... the question is how far the judgment promotes and preserves life, how well it preserves, and perhaps even cultivates [it]." ${ }^{86}$ Based on such remarks from Nietzsche's later writings, we can elaborate and proceed with Zimmerman, ${ }^{87}$ with an odd classification between 'true

\footnotetext{
81 Ibid.

${ }^{82}$ Nietzsche, Writings from the Late Notebooks, Section 34[167], p. 11.

${ }^{83}$ Ibid, p. 9.

${ }^{84}$ Ibid.

${ }^{85}$ Nietzsche, Beyond Good and Evil, trans. R. J. Hollingdale (New York: Penguin Books, 1990), p. 122

${ }^{86}$ Ibid., p. 7.

${ }^{87}$ Robert L. Zimmerman, The Kantianism of Hegel and Nietzsche (New
} 
falsities' and 'false falsities'. In other words, there are expressions and beliefs which do not correspond to states of affairs, and yet at the same time offer benefits to those who affirm them. And there are also other statements and beliefs that neither correspond to given state of affairs nor benefit those who affirm them. The former can be called just false or fictional (true falsities), while the latter are doubly false (false falsities), so to speak. As far as Nietzsche's corpus is concerned, the 'false falsities' might be those errors which are maximally detrimental, but are nonetheless minimally neutral for preserving and enhancing the life of the human species. But all truths are still deemed true falsities because they are creative (Apollonian) fictions without which the human race is unable to sustain itself. Thus as "a higher and more fundamental value for all life," truth possesses a decisive status in determining what we can accept and what we cannot in our lives. Even the most false judgments, such as synthetic a priori judgments, would be "most indispensible," contends Nietzsche, insofar as they bolster our strength and capacity to grow in life. Discursive efforts have value to the extent to which they serve and sustain human life, and truth as the "unconditioned and self-identical" stems from life-preserving formulas and measurements. The insecurity in human existence can be overcome by conforming to a certain kinds of 'true-falsities' or 'untruth,' as Nietzsche writes, by 'accepting the fictions of logic... measuring reality against the wholly invented world... [and] a constant falsification of the world through numbers." ${ }^{88}$ Within the scope of existential Kantianism, Nietzsche reconceived a priori categories and logical correlates which operate as the foundational principles of language. Similarly, all transcendental assumptions, thinks Nietzsche, are based on a set of non-veridical claims which we have appropriated in order to shield and sustain our consciousness. Metaphor issues forth from the same existential-pragmatic urge which minimizes the whirling complexity of human experience, and therewith calculate the inconstant and immeasurable for the service of a smooth execution of human life. The world as a given and independent existence, as Zimmerman puts it, needs to be routinely "re-worked, re-processed, re-presented" via the process of metaphorization, and, in this specific sense, our narcissisms are covered up in our discursive and ontological efforts. They are "reified, ontologized, alchemically objectified or renovated as the structure of reality." 89

One of the main goals of Nietzsche's criticisms is to establish the fact that the rules and laws of language are essential for communicating reality, and that they express the world truthfully if they encode human life artistically; not by discounting dissimilarities and differences amongst entities, nor by absolutizing truths. Nietzsche redefined intellect and understood it as a motion of artistic fluidity. As he himself puts it, "art as a will to overcome 'becoming' as

\footnotetext{
York: The Edwin Mellen Press, 2005), p. 5.

${ }^{88}$ Nietzsche, Beyond Good and Evil, p. 7.

${ }^{89}$ Zimmerman, The Kantianism of Hegel and Nietzsche, p. 7.
}

"eternalisation," and suggests thereby a "short-sighted depending on perspective: reiterating in the detail, as it were, the tendency of the whole." 90 While the working of the senses is "creating, logicizing, trimming, falsifying," 91 Nietzsche investigates another deeper question, namely, whether the senses can create the world in many ways, as he informs us in the same passage: "The effect of the external world upon us" is real, and the apparent world is "the best-guaranteed reality." 92

With his most polemical claim that "truth is the mobile army of metaphors," Nietzsche in no way argues that truths are merely intellectual fabrications, and hence pseudo-claims, having no empirical content. He instead suggests that truths become false only if they are absolutized through forgetting or by denying the fact of their primordial groundedness in necessity and the need which underpins our "will to know and explain." 93 It is important to follow Nietzsche's distinction between pre-linguistic and linguistic thought which is referred to as existentially-grounded intuition. ${ }^{94}$ But, in Nietzsche's view, pre-linguistic thought is also different from non-linguistic thought. ${ }^{95}$ The non-linguistic indicates the phenomenal world as such, which is unmediated and inaccessible to language. While the pre-linguistic world is intuitive, the linguistic can be both abstract and conceptual. And while linguistic thoughts are interpersonal, and so transcend the sphere of the subjective, intuitive thought is communicated both by language and non-linguistic means; it expresses the insatiable thirst and ideal need for wisdom and values of life. ${ }^{96}$ Philosophical minds with higher insights, Nietzsche contends, can directly intuit ideas:"so fulfilling, enhancing, elevating and purifying the elements they take over... that they [philosophers] become inventors... but in a higher sense and a purer sphere." 97 Their inventions do not provide technical or instrumental knowledge of craftsmanship, but, Nietzsche believes, this non-provable analogical thinking is rich and strong in directly reaching out to the non-mythical and non-allegorical sphere of reality.

As regards the objective side of relational knowledge, Nietzsche tells us that humankind seeks for a true world, "a world... not self-contradictory, not deceptive... [and] does not change." 98 And, importantly, we invent an artistic world that sooths us and protects us from existential crisis, "a world in which one does not suffer" from "contradiction, deception, change - causes of suffering." 99 In the

\footnotetext{
${ }^{90}$ Nietzsche, Late Notebooks, Section 7[54], p. 138.

91 Ibid., section 9, p. 106.

92 Ibid.

93 Ibid., p. 143

${ }^{94}$ Nietzsche, Philosophy in the Tragic Age of the Greeks, trans. Marianne Cowan (Washington, D.C.: Regnery Gateway, 1991), p. 28.

${ }^{95}$ Sadler, Nietzsche: Truth and Redemption, p. 32.

${ }^{96}$ Nietzsche, Philosophy in the Tragic Age of the Greeks, p. 31.

${ }^{97}$ Ibid.

${ }^{98}$ Nietzsche, The Will to Power, trans. Walter Kaufmann and R. J.

Hollingdale (New York: Vintage Books, 1968), section 585[A], p. 316.

99 Ibid.
} 
Notebooks, Nietzsche denies the Platonic-Kantian distinction between "apparent world" and "true world,"100 and with the disappearance of the antithesis between the two worlds, "abolished the thing in-itself and with it the one... of "appearance." 101 Indeed, the world in-itself for Nietzsche does not transcend the phenomenal realm, but is a domain of unformulated and unruly sensations - Dionysian chaos which amounts to Nietzsche's version of the world as grasped by the higher intellect. At this point, Nietzsche confronts a perennial concern vis-à-vis the inevitable presence of truth-metaphysics for human life. Much like Kant, Nietzsche reworks his view and argues that the metaphysical dimension of our discursive efforts is unavoidable, and yet inaccessible to the intellect: "[t]here could be a metaphysical world... an absolute possibility of it is hardly to be disputed." "102 Furthermore, even if the human race were to cease perceiving the world, "[t]he world would still be there if one had cut [one's head] off." ${ }^{103}$ This argument reoccurs in various forms in the Notebooks, reiterating the classical idealism of the inconceivability of a determinate, non-perspectival and objective reality. The issue was originally taken up and pushed to an extreme by Berkeley, but was later reworked differently by both Kant and Schopenhauer. Nietzsche concentrates on the dissimulation of intellect in line with Schopenhauer's view that the intellect knows only representations, "an illusion generated by the unending play of the metaphysical entity", the will. ${ }^{104}$ In Schopenhauer's case, this manifestation occurs through various subjective structures that are mutually interested, causally dependent and inclined towards our practical concerns; but in Nietzsche's context, it takes on a phenomenological-existential direction. Nietzsche's own position leads to Dionysianism, a view which is existential-pragmatic rather than metaphysical (Schopenhauer) or transcendental (Kant).

Despite the deeper complexity of sensory mechanisms and the problematic nature of direct correspondence, Nietzsche insists that "we must not conceive of our intellect as ... contradictory," that is, consider it as both "a belief and a knowledge of that belief." 105 Nietzsche relies on the capacity of the senses, and his trust eventually rests on a phenomenological stance. As he himself writes, "[w]e no longer need any excessive oppositions, any oppositions at all... we may love the senses, we have intellectualized them and made them artistic in every degree."106 To him, the antithesis arises out of a false and redundant divide between what we actually perceive while we perceive, and what we cannot perceive but we believe we miss to perceive. Kant's antithesis is rendered null and void and, ultimately, is reduced to the one between this world and nothing.

\footnotetext{
100 Nietzsche, Late Notebooks, p. 126.

101 Ibid.

102 Nietzsche, Human, All Too Human, p. 15.

103 Ibid.

104 Nietzsche, The Birth of Tragedy, p. vii.

105 Nietzsche, Notebooks, p. 126.

106 Ibid.
}

Phenomena seem to be cheating; as Nietzsche writes, "phenomenalism ... [has] a character as mask,"107 and one would find nothing behind or beyond the phenomenal world either. Blondel has put this point nicely when discussing Nietzsche's elusive combination of the truth and falsity of the phenomenal world:

It is certainly true that life deceives us with her ambiguous apparitions: but she deceives us not because she conceals an essence or a reality beneath appearances, but because she has no essence and would only like to make us think she does. Her essence is to appear. ${ }^{108}$

The conditions of our existence are inevitably there under which the senses are to function. Even the relations of magnitude, for instance, appear "as qualities with regard to the necessary conditions of our existence."

In exploring the metaphorical fluidity of language, Nietzsche put aside the old metaphysical debates of 'what is?', and instead asked the basic question 'which one'? In this paradigmatic shift, Nietzsche abandons the listener's view, that is, the Socratic-Platonic stress on the 'whatness' of being, and assumes a speaker's perspective on humankind's life-experience, as defined by the will to know. Looking through a Dionysian lens, Nietzsche subverts the common perception about language and ventures to reformulate it as a suitable domain for free spirited philosophers. Or as Nehamas proposes, Nietzsche oftentimes thought that his free subjects would be far-sighted and free from any illusory experience. ${ }^{110}$ Nietzsche himself confirms that the complete freedom of existential subjects from error is indeed possible:

One could conceive of delight and power of self-determination, a freedom of the will, in which the spirit takes leave of all faith and every wish for certainty, practised as it is in maintaining itself on light ropes and possibilities and dancing even beside abysses. Such a spirit would be the free spirit par excellence. ${ }^{111}$

In Nietzsche's view, and seen from the speaker's perspective, the notion of an essentialized entity is void, and thus should be reformed as a Dionysian object that undergoes plurality, change and becoming. In other words, individual subject-matters would require us to perceive entities and events from inside-out, routinely reworking and readopting it, and thereby reconstituting every experience. Through the act of knowing, Nietzsche maintains, we cannot achieve a God's eye view or arrive at an universal 'whatness'; instead, we apprehend particularities in and about entities in accordance with existential as well socio-cultural necessity. Cognition is not decisively hostile to instinctual needs and necessities, and indeed does not clash with our existential accomplishments. In Nietzsche's

\footnotetext{
${ }^{107}$ Ibid., p. 85.

${ }^{108}$ Allison, The New Nietzsche, p. 157.

${ }^{109}$ Nietzsche, Late Notebooks, section 5[36], p. 111.

${ }^{110}$ Nehamas, Nietzsche, p. 61.

${ }^{111}$ Friedrich Nietzsche, The Gay Science, trans. Josefine Nauchhoff \& Adrian Del. Caro, ed. Bernard Williams (Cambridge: Cambridge University Press, 2001), section 347, p. 206.
} 
analogy, cognition bears a similar relation as the "act of birth" does to "heredity." 112 Nietzsche's subject, it follows, does not possess a Cartesian self-evident mind, but an existential one; he or she is interested in, and is even biased towards, his or her own feeling-sensing-thinking. Unlike their Cartesian counterparts, existential subjects start from the scratch, and "renovate or refract the reality, i.e., re-order their perceptions of it in terms of their pragmatically grounded a priori organismic standpoint." 113 In this new mode of subjectivity, the existential subject is removed from passive metaphysical construction, and becomes an active and willful observer of the world.

Nietzsche traces a constant precariousness in the primordial stage of human will, that is, an empty human condition deprived of all meaningful structures, values or essences. In fact, any individual subject living in the abyss of existential state is readily prone to create, and thereby get rid of the anxieties arising from the non-knowledge or ignorance. In the opening sentences of On Truth and Lying in Non-Moral sense, Nietzsche depicts this nihilistic condition of existential minds wherefrom the original will to know first sprouted, and maintains that the greatest of human accomplishments (the ability to know) soothes us in the face of the greatest discomfort, fear and anxiety which underlie our confrontation with the unknown. Underpinned by such a fundamental urge, we are predisposed to color our perception of inner facts and their causal relations to the external world, and thereby execute our efforts to know or explain the reality that surrounds and protects us. Embodying this natural innocence of sharing and inhabitedness, humankind emerged as the most creative being in the world not in the sense of a Cartesian sovereign subject, but in the sense of an aesthetically productive yet redeeming social being. Thus, for Nietzsche, language has become a crucial function of will to know. In other words, language needs to be viewed from its existential as well as phenomenological side. Nietzsche reiterates the fact that meaning is not purely linguistic, but cognitive as well. To know is to be existentially interactive, and so a subject's participation in the world coincides with truth in particular and knowledge in general. In other words, the world, though given and objective, constantly evolves out of a process of subjective reworking. Truth occurs whenever the existential subject consciously alienates himself from the unity of nature, ventures to model his own ego or self, dictated by individual necessity and motivations as well as the commitment to sharing with and recognition of the other. Truth thus essentially requires a set of external stimuli triggered by a durable and independent world. The notion of a durable world the Dionysian deems absurd because the existential subject has to pin down constants and truths from the world of becoming and emergence.

According to common belief, Nietzsche denies the correspondence theory of truth and allegedly argues that,

\footnotetext{
${ }^{112}$ Nietzsche, Beyond Good and Evil, p. 7.

113 Zimmerman, The Kantianism of Hegel and Nietzsche, p. 6.
}

since it consists of metaphors and not concepts, language does not portray reality as such. To put it differently, he is thought to deny the possibility of knowledge of an independent sphere of reality. But, at the very outset of his early essay, Nietzsche alludes to the independent presence of a material realm and its infinite space that is filled with dusty stars and meteors:

In some remote corner of the universe, flickering in the light of the countless solar systems into which it had been poured, there was once a planet on which clever animals invented cognition... After nature had drawn just a few more breaths the planet froze and the clever animals had to die... there were eternities during which it [human intellect] did not exist; and when it has disappeared again, nothing will have happened. ${ }^{114}$

Firstly, Nietzsche declares that cognition is not just a given phenomenon for humankind; instead, it emerged gradually and progressed as we learnt to better adapt with and adjust to natural unity. Humankind has become the most intelligent of all creatures by means of precisely this useful invention. In this socio-hermeneutic approach to cognition, Nietzsche signals to the polemic of nature versus culture, wherein he set his sights on the unity of the universe, and therewith seeks to show how humankind had removed itself from the primordial tie with unity, and eventually lost the innocence of existence. While reflecting on the problem of truth and cognition as a whole, Nietzsche never lost sight of existential-pragmatic concerns. To him, this psychic alienation is akin to a big punishing event for humankind, which was ironically compensated for by a reciprocal emergence of the self-conscious ability to cognize. For the human race to be a truly human type, knowing appears as an indispensible and worthwhile break from the original animal condition. Nietzsche cast a complex attitude on this unique invention: sometimes as an initiator of "arrogance" and "mendaciousness," sometimes as a mark of comfort and security. In such a portrayal of cognition, Nietzsche theorized that truth could be taken as a phenomenon which can neutralize the extreme effect of Dionysian nihilism. As a truth that crosses the limit of humanness, the Dionysian worldview undoes humankind's journey towards humanization. In Nietzsche's existentialism, truth eventually becomes the saviour of mankind in its concealed and dark past, and presents itself to us as a tool for facing the finitude and anxiety of individuation.

The idea that metaphors do not have any bearing for entities themselves contradicts the whole evolutionary history of mankind. If evolution is real, Homo sapiens is the outcome of an inner chemistry of a physical universe. No matter how difficult it is to formulate a clear and distinct view, a certain correspondence between our evolved body, mind and ideas, on the one hand, and the physical reality of the universe, on the other, is plausible, and thus has to be pre-conceived. Nietzsche's concern is not to deny the metaphysics as such, but rather to explore the issue of how a

\footnotetext{
114 Nietzsche, On Truth and Lying in a Non-Moral Sense, p. 141
} 
true and all-too human account of appearance could be possible. In his critical enterprise, Nietzsche differed from Kantian metaphysics with his strong contention that there is no story to be authored behind or beyond what our senses can provide us. But our senses are fashioned in such a way that, Nietzsche suggests, we cannot penetrate the things themselves in a direct and unmediated way; instead, our "eyes merely glide across the surface of things and see forms." 115 Truth is anthropocentric, that is, knowledge is obviously a humanizing activity: "nowhere does their perception lead into truth... it is content to receive stimuli... as it were, to play with its fingers on the back of things."116 But to argue that perception is subjective is not to confirm the view that what we know does not correspond to an external world. That knowledge-concepts are metaphorical does not deny the basic impressions of and about an objective universe, but affirms the view that concepts are derived and reworked as a product of our conscious mind. The "senses do not lie," nor do they prevent us from knowing the world; they truthfully represent the world and do not jeopardize common sense. Nietzsche, in other words, does not make any naïve claim which purports to deny the testimony of common-sense and everyday realism.

\section{Concluding Remarks}

In Nietzsche's early account of truth, linguistic abstractionism is uncannily mixed with existential truth and has much in common with the Semitic ${ }^{117}$ epistemologies. But his account is far removed from the immoralism of relativism and deconstruction. Nietzsche deciphers truth as an agreed upon metaphor to stabilize becoming, and it functions as a comforting illusion in our ephemeral life; as Deleuze famously suggests, Nietzsche's views might be "criminal and blameworthy but not... faulty and irresponsible." 118 Committed to a form of pragmatism, Nietzsche prefigured truth as a conditional for peculiar human situations, and not as something which is unconditional and beyond mutation. Fusing the value of

\footnotetext{
${ }^{115}$ Nietzsche, The Birth of Tragedy, p. 142.

116 Ibid.

117 An adjective, the word Semitic is derived from Shem, one of the three sons of Noah in the Genesis. The Greek derivative of that name is Sém, a noun that refers to anyone who is a Semite. The word Semitic now refers to the main religions (Judaism, Christianity, Islam) which originated in the Middle East region. Instead of Semitic, the term Abrahamic is more commonly used today. Manichean and Mandaean religions also fall within this category. However, the truly comprehensive account of Semitic religions also includes other ancient religions that flourished in the region long before the Abrahamic religions. It may be relevant to mention that Manichaeism considers Zarathustra as a prophetic figure (along with Jesus and the Buddha) of whom Mani (216-276) is the last prophet. Zarathustra's ethical dualism is largely incorporated in Mani's doctrine, which views the world as an epic battle between the opposing forces of good and evil. Apart from Zarathustra's teachings, Nietzsche is thought to be a supporter of Manichaeism (the dualism of light and darkness). See Robert C. Solomon, Living with Nietzsche (Oxford: Oxford University Press, 2003), p.65

${ }^{118}$ Deleuze, Nietzsche and Philosophy, p. 20.
}

truth with life-affirmation, Nietzsche strangely configures the truth of a becoming world suspending the movement of opposition or negativity. As portrayed in the exemplary character of Zarathustra, ${ }^{119}$ Nietzsche dismisses the dialectics of binaries, and therewith issues a double affirmation of becoming as an eternally recurring lived-world which is symbolized by the event of Zarathustra's descent into human society. In his first publication, Nietzsche outlined this fusion as Dionysian truth, but reconstituted the notion in a positive way by means of Zarathustra's thoughtful sermons. The necessity for truth is a common need for humankind and, as Nietzsche intimates in Daybreak, the sense of truth has sprung from the sense of security which is also the original necessity of all living beings. ${ }^{120} \mathrm{He}$ insists that we need to believe that, with a sense of higher truth, "one would much rather suffer and thereby feel oneself exalted above reality." 121 Such a Nietzschean formulation, I contend, does not culminate in any ultimate suspicion or denial of truth. Instead, this view is constructive and based on an inexhaustible repetition of inquiry that is envisaged by the "forward-striving spirit." 122 In early works, Nietzsche outlined what this forward looking insight looks like. Mesmerized by the existential myths about the heroic acts of tragic figures in Hellenic culture, Nietzsche elaborated his philosophical mission by maintaining that "[i]f philosophy ever manifested itself as helpful, redeeming or prophylactic, it was in a healthy culture." 123 Thus the forward-looking-subject, suggests Nietzsche, will be bred "whenever it [philosophy]... exists in his fullest right," "124 not by isolating, but by reintegrating the lives of individual subjects from his existential history. In a certain sense, Nietzsche used his Heracletian intuition to bring out a new genre of thinking and, therewith, rehabilitated a metaphorical grasp of the life-world for a more progressive and advanced generation of a future humankind. Thus imagination plays a key role in philosophical thinking as equally as it does in poetry. This new type of philosopher, remarks Deleuze, "knows in that he invents, and he invents in that he knows." 125 The

\footnotetext{
119 Zoroaster, popularly known as Zarathustra, is the founder of Zoroastrianism, and was born in the eastern part of ancient Persia. He is thought to have authored two books: Yasna Haptanghaiti and Gathas. Most of his life is known through these texts. In the Gathas (hymns), Zarathustra sees the human condition as a psychological struggle between $a \check{s} a$ (truth) and $d r u j$ (lie). The cardinal concept of aša is the foundation of his doctrines, such as the god Ahura Mazda is $a \check{s} a$, creation is $a \check{s} a$, existence is $a \check{a} a$ etc. The condition for free will is considered as Zarathustra's greatest contribution to philosophy. Nietzsche is greatly influenced by Zarathustra's vision of existential truth ( $a \check{s} a)$. To Zarathustra, the purpose of all existence is to sustain $a \check{s} a$. For us human beings, according to his teaching, this truth is achievable through active participation in life and the exercise of constructive thoughts, words and actions. Among the classical Greek philosophers, Heraclitus was also inspired by Zarathustra's thinking.

${ }^{120}$ Nietzsche, Daybreak, p. 21.

${ }^{121}$ Ibid., p. 24

${ }^{122}$ Nietzsche, Will to Power, Book 2, , p. 91.

${ }^{123}$ Nietzsche, Philosophy in the Tragic Age of the Greeks, p. 27.

${ }^{124}$ Ibid., pp. 27-28.

${ }^{125}$ Deleuze, Nietzsche and Philosophy, p. 150.
} 
imagination permits us, Deleuze continues, to "grasp analogies... [but] reflection intervenes... to replace them with equivalences, to replace successions with causal relations, and to bring the measure of the concept to bear." ${ }^{126}$ Nietzsche's early essay On Truth and Lying in the Non-moral Sense negotiates the antithesis between intuition and reflection, and offers a new vision of life-experience. Since the Socratic era, philosophers have been working intensely with the rational faculty, and, to paraphrase Kofman, logic and reason took an upper hand over intuition, and Aristotle came to prevail over Heraclitus and the artistic drive. ${ }^{127}$ But this new spirit of philosophical thinking, with Nietzsche, merges again with its good old friend, but remains truthful at the same time to its own tradition of over two millennia. The new genre of thinkers will be critically engaged with their lived-world, while also remaining cautious of the world's mythical orientations. Simply put, the world for Nietzsche continues to thrive and behave as if it were, to refer to the Heraclitian metaphor, a river that is ever-flowing; as if it were a "Zeus's game." 128 With this elusive perspective in mind, Nietzsche writes in The Philosophy in the Tragic Age of the Greeks that "[e]verything forever has its opposite along with it." new philosopher would view the world of becoming as multiplicity by appealing to reason, but as oneness by appealing to poetic intuition. The becoming of the world, as a metaphor of Zeus's game, would be both intuited by an artist and known by the Nietzschean philosopher. As Nietzsche has pointed out, "[1]ife's artistic drive is constantly bringing new worlds into being, with as much freedom and necessity as there is in play." 130 The world is not infinite, but singular and limited, and yet it "includes infinite interpretations." 131 As Nietzsche comments on numerous occasions, the world is pluralistic and, to cite Nehamas, "in the sense that the world has a character, and there can be many complete interpretations of the world."

Such a Nietzschean position on language becomes popular in the Franco-American camp of scholars during the 1960s and 1970s. While labeling Nietzsche as the chief architect of deconstruction, they (e.g. Paul de Man, Derrida) laid out his philosophy as dismissive of cognition and morality. Though heterogeneous in their focus and intent, the vast body of their publications makes a sweeping claim that Nietzsche sacrificed truth to the repetitive task of interpretation. This current also suggests the view that truth is merely a linguistic construct, and that the external world is an idealized entity, and thus has only a derivative existence. This view is underpinned by a grammatological survey of language. What is problematic with this is that it invokes nihilism, and makes human life purposeless. Humankind,

\footnotetext{
126 Ibid., p.53.

${ }^{127}$ Kofman, Nietzsche and Metaphor, p. 20.

128 Ibid., p. 21.

${ }^{129}$ Nietzsche, Philosophy in the Tragic Age of the Greeks, p. 52.

${ }^{130}$ Ibid., p. 62

${ }^{131}$ Nietzsche, The Gay Science [373], pp. 239-240.

${ }^{132}$ Nehamas, Nietzsche, p. 64
}

according to this view, cannot reach the truth, the good or the beauty because, as ends, these concepts are relative or undecidable. Also, this view claims that humankind is entangled in an unavoidable and arbitrary playful act of signs, and so we are encircled by confusion, nonknowledge, even ignorance. This position insists that grammatical features single-handedly guide our cognitive ability, and so govern and fashion our capacity for thinking about reality. That is, language, even while we use it to express what is external to us, produces the totality of the subject-object duality. Considering language as arbitrary, we cannot get rid of this circularity even for a moment, because this very undecidedness in turn determines who we are as human beings.

But to know truth as metaphorical for Nietzsche is, as Nehamas argues, ${ }^{133}$ just to recognize that we can liberally accept the plurality of views on and perspectives about an event. While considering our relation with the world, Nietzsche does not simplify life-experience as arbitrary or undecided; in fact, no one can even think of doing so. Nietzsche wrote in The Gay Science that "truth is created and not discovered,"134 but he also insists that we must think of it as something we discover in order to go on to create it. $^{135}$

Nietzsche understands truth as an overly metaphysical category, as if it is always tested according to the strict criterion of metaphysical equivalence. An utterance would be qualified as true in a broad sense as well, because the world as becoming resists our tendency to make absolute claims about it. If Nietzsche refers fiction to something that is deceptive, then this should not be taken as the logical opposite of truth. Furthermore, if fiction is equated with linguistic arbitrariness or relativism, then Nietzsche's claim would amount to the view that humankind breathes and lives only in a world of linguistic undecidedness and epistemological confusion. Derrida's deconstruction, the assertion that language is a function of signifiers with arbitrary meanings, thus paralyses epistemological efforts in such a way that we are embroiled with and in incurable undecidedness while saying anything whatsoever about the world. Though mediated by language, true assertions consist of what they mean, that is, with regard to the world. Precisely in this 'whatness' consists the non-linguistic independent world which, via utterances, we truly and precisely speak about. Linguistic arbitrariness or relativism is neither necessary nor sufficient for what humankind knows about truths concerning the lived-world. But engaging critically with the rules and conventions of language might be, as Clark suggests, "a great practical help for figuring out the meaning of an utterance."

While taking on the nihilistic view of the Greek god Silenus in The Birth of Tragedy, Nietzsche reminds us of the

\footnotetext{
133 Ibid., p. 61.

${ }_{134}$ Nietzsche, Beyond Good and Evil, section 211, p. 106.

135 Nehamas, Nietzsche, p. 59

${ }^{136}$ Clark, Nietzsche on Truth and Philosophy, p. 69.
} 
fact that we "grasp, intuitively, of the necessity of... two things" 137 - first, the Apollonian world of truth and beauty and, second, the primordial unity of nature. By means of the Apollonian reconstitution of the world with the principle of individuation, the unity of nature releases and redeems itself, and in that way attains its eternally set goals. As a result of this deification, the real world of semblance, that is, the world as becoming, comes into existence. ${ }^{138}$ Nietzsche further writes that these sublimated forms of truth help us to escape from the "world of agony" and be "lost in contemplation of that vision, to sit calmly in his rocking boat in the midst of the sea." ${ }^{, 139}$ But down in the same passage Nietzsche cautions us about the danger of excess, and so reminds us of the "limits of the individual measures in the Hellenic sense." 140 The aesthetic necessity of truth and beauty, claims Nietzsche, has to be authored after Hellenic demands, that is, those ethical imperatives that were inscribed on the door of Apollo's temple: "Know thyself" and "Not too much.", "Getting above oneself and excess," Nietzsche warns us again, would be "regarded as the true hostile demons of the non-Apollonian sphere, and thus as qualities of the pre-Apollonian period, the age of the Titans, and of the extra-Apollonian world, that of the barbarians."142 As a far-sighted pedagogue and cultural physician, Nietzsche observes that excessive suspicion in knowledge might lead to a position where one can only "believe in belief and thereby destroy everything that prospers by means of belief (i.e. life itself)." 143 While mild skepticism functions as a belief in the power of logic itself, Nietzsche rejects its extreme form that starts with doubting reason and culminates with its total negation. Nietzsche locates this extreme form in pure nihilism, and warns of its dangerous consequences: "No one can live within such a denial of reason, no more than within pure asceticism." 144

\section{References}

[1] Allison, David B., ed., The New Nietzsche: Contemporary Styles of Interpretation, (New York: Dell Publishing, 1977).

[2] Clark, Maudemarie, Nietzsche on Truth and Philosophy, (Cambridge: Cambridge University Press, 1990).

[3] Deleuze, Gilles, Nietzsche and Philosophy, trans. Hugh Tomlinson, (New York: Columbia University Press, 2006).

[4] Hofstadter, Douglas R., "Epilogue: Analogy as the Core of Cognition," The Analogical Mind, eds. Dedre Gentner, Keith J. Holyoak and Boicho N. Kokinov, Massachusetts: Massachusetts Institute of Technology Press, 2001.
[5] Klossowski, Pierre, Nietzsche and the Vicious Circle, trans. Daniel W. Smith, Chicago: The University of Chicago Press, 1997.

[6] Kofman, Sarah "Metaphor, Symbol, Metamorphosis," in Allison, David B., ed., The New Nietzsche: Contemporary Styles of Interpretation, New York: Dell Publishing, 1977.

[7] Nehamas, Alexander, Nietzsche: Life as Literature, Cambridge: Harvard University Press, 1985.

[8] Nietzsche, Friedrich, Human, All Too Human, trans. R.J. Hollingdale, Cambridge: Cambridge University Press, 1996.

[9] Nietzsche, Friedrich, The Birth of Tragedy and Other Writings, ed. Raymond Geuss, trans. Ronald Speirs, Cambridge: Cambridge University Press, 1999.

[10] Nietzsche, Friedrich, On Truth and Lying in a Non-Moral Sense, in The Birth of Tragedy and Other Writings, eds. Raymond Geuss and Ronald Speirs, trans. Ronald Speirs, Cambridge: Cambridge University Press, 1999.

[11] Nietzsche, Friedrich, Writings from the Late Notebooks, trans. Kate Sturge, ed. Rudiger Bittner, Cambridge: Cambridge University Press, 2006.

[12] Nietzsche, Friedrich, Daybreak: Thoughts on the Prejudices of Morality, trans. R. J. Hollingdale, eds. Maudemarie Clark and Brian Leiter, Cambridge: Cambridge University Press, 2006.

[13] Nietzsche, Friedrich, Philosophy and Truth - Selections from Nietzsche's Notebooks of the Early 1870's, ed. \& trans. Breazeale, Daniel, New Jersey: Humanities Press International Inc., 1993.

[14] Nietzsche, Friedrich, The Portable Nietzsche, trans. \& selected, Walter Kaufmann, New York: Penguin Books, 1982.

[15] Nietzsche, Friedrich, Philosophy in the Tragic Age of the Greeks, trans. Marianne Cowan, Washington: Regnery Gateway, 1991.

[16] Sadler, Ted, Nietzsche: Truth and Redemption-Critique of the Postmodernist Nietzsche, New Jersey: The Athlone Press, 1995.

[17] Quine, William van Orman, From a Logical Point of View, New York: Harper and Row, 1963.

[18] Zimmerman, Robert L., The Kantianism of Hegel and Nietzsche, (New York: The Edwin Mellen Press, 2005).

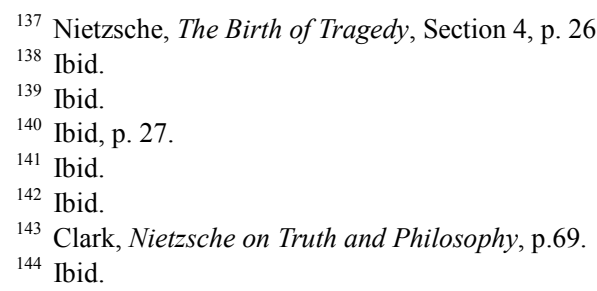

